\title{
Hubungan Penggunaan Terapi Modern dan Komplementer terhadap Kualitas Hidup Pasien Kanker Payudara
}

\author{
Erna Irawan ${ }^{1}$, Laili Rahayuwati ${ }^{2}$, Desy Indra Yani ${ }^{2}$ \\ ${ }^{1}$ Fakultas Keperawatan, Universitas BSI, ${ }^{2}$ Fakultas Keperawatan, Universitas Padjadjaran \\ Email: stnaira@gmail.com
}

\begin{abstract}
Abstrak
Kejadian kanker payudara yang meningkat di Indonesia berpotensi terhadap penurunan kualitas hidup manusia. Secara umum, dalam rangka peningkatan kualitas hidup, pasien memilih terapi modern meskipun di sisi lain terdapat efek fisik pasca terapi. Selain itu, untuk mengurangi efek terapi modern dan melengkapi terapi modern dalam meningkatkan kualitas hidup pasien kanker payudara dilakukan terapi komplementer namun belum banyak penelitian yang membahas hal tersebut di Indonesia. Tujuan penelitian ini untuk mengidentifikasi hubungan penggunaan terapi modern dan terapi komplementer (herbal, pijat, dan herbal-pijat) terhadap kualitas hidup pasien kanker payudara yang menjalani kemoterapi. Penelitian ini adalah jenis korelasi yaitu hubungan antara dua atau lebih variabel dengan pendekatan cross sectional dan analisis data dengan Spearman test. Pengambilan data berdasarkan kuesioner penelitian sebelumnya, meliputi terapi modern, terapi komplementer, dan kualitas hidup terhadap 178 responden yang diambil dengan teknik accidental sampling. Hasil penelitian menunjukkan terapi modern dan komplementer berhubungan positif dengan kualitas hidup $(\rho$-value $=0,00, \rho($ rho $)=+0,2)$, terapi modern secara bermakna berhubungan positif dengan kualitas hidup $(\rho$-value $=0,00, \rho($ rho $)=+0,5)$ dan terapi modern dengan herbal secara bermakna berhubungan positif dengan kualitas hidup $(\rho$-value $=0,00, \rho($ rho $)=+0,4)$. Adapun kombinasi terapi modern dan pijat $(\rho$-value $=0,57, \rho($ rho $)=-0,1)$ dan terapi modern, pijat, dan herbal tidak berhubungan dengan kualitas hidup $(\rho$-value $=0,4, \rho($ rho $)=+0,2)$. Perawat komunitas dapat memberikan informasi mengenai pentingnya terapi modern bagi kualitas hidup penderita kanker payudara. Penelitian lebih lanjut mengenai lama, intensitas, dan pemberi herbal sebagai pelengkap terapi modern dalam meningkatkan kualitas hidup pasien kanker payudara.
\end{abstract}

Kata kunci: Kanker payudara, kualitas hidup, terapi komplementer, terapi modern.

\section{Relationship between Modern and Complementary Therapies on the Life Quality of Breast Cancer Patients Undergoing Chemotherapy}

\begin{abstract}
The prevalence of breast cancer has impacted on a decrease in their life quality. However, it can be improved by modern therapy, despite any post-therapy physical problems to occur. Complementary therapies used to reduce the effects of complete modern therapy. The purpose of this study to is to analyze the correlation between modern and complementary therapies (herbal, massage, and herbal-massage) on the life quality of breast cancer patients undergoing chemotherapy. The research method used cross-sectional study and the Spearman test for data analysis. Data were collected by previous research questionnaire, covering modern therapy, complementary therapies, and the life quality of 178 respondents based on the criteria accidental sampling. The survey results positive in terms of the life quality between modern and complementary therapy $(\rho$-value $=0.00, \rho($ rho $)=+0.2)$, in terms of modern therapy $(\rho$-value $=0.00, \rho($ rho $)=+0.5)$, and between modern and herbal therapy ( $\rho$-value $=0.00, \rho($ rho $)=+0.4)$. However, modern therapies and massages do not show any relation to the life quality ( $\rho$-value $=0.57, \rho($ rho $)=-0.1)$. Like modern therapy, both massage and herbs are also not related $(\rho$-value $=$ $0.41, \rho($ rho $)=+0.2)$. The nursing community, however, can provide further understanding of the modern therapy to the life quality of the patients. Upcoming research about the time cost, healthcare intensity, and criteria of herbal therapy provider is required as a contribution to improve the life quality of breast cancer patients.
\end{abstract}

Keywords: Breast cancer, complementary therapy, modern therapy, quality of life. 
Erna Irawan : Hubungan Penggunaan Terapi Modern dan Komplementer

\section{Pendahuluan}

Sejak tahun 2005 sampai dengan tahun 2010, WHO memperkirakan ada 58 juta kematian karena penyakit-penyakit kronik dan 7.6 juta disebabkan oleh kanker. Saat ini terdapat tiga jenis kanker sebagai penyebab kematian utama pada wanita di dunia yaitu kanker payudara, kanker paru, dan kanker serviks dimana kanker payudara menjadi penyebab paling umum untuk kematian di kalangan wanita dengan jumlah 425.000 orang.

Jumlah penderita kanker payudara semakin meningkat. Pada tahun 2012, penderita kanker payudara di dunia sebanyak 1,7 juta dan diperkirakan akan meningkat menjadi empat kali lipat pada tahun 2020 (WHO, 2012). Insidensi kanker payudara adalah $20 \%$ dari seluruh keganasan (American Cancer Society, 2011).

Di Indonesia jumlah penderita kanker payudara adalah 61.682 dengan prevalensi 12/100.000 wanita (Kementrian Kesehatan Republik Indonesia, 2015). Penderita kanker payudara menyebar diseluruh provinsi. Jawa barat merupakan provinsi ketiga terbanyak untuk penderita kanker payudara, yaitu 6.701 orang dengan prevalensi $0.3 \%$ (Kementrian Kesehatan Republik Indonesia, 2013).

Risiko terjadinya kanker payudara semakin meningkat dengan peningkatan usia. Kasus kanker payudara banyak terjadi pada rentang usia 30 sampai dengan 50 tahun (Ostad \& Parsa, 2011). Perempuan yang berusia lebih dari 50 tahun lebih berisiko terkena kanker payudara (Kementerian Kesehatan Republik Indonesia, 2013).

Efek kanker payudara adalah perubahan kondisi dari fisik, psikologis, sosial, dan spiritual yang menyebabkan kualitas hidup dari pasien menurun (Fatmadona, 2015). Masalah fisik yang sering terjadi seperti nyeri pada bagian payudara, adanya perubahan warna pada payudara, pusing, dan masalah tidur (Fatmadona, 2015). Masalah psikologi seperti perasaan sedih, takut, cemas, marah, dan lainnya Sedangkan masalah sosial yang muncul seperti malu ketika bertemu dengan orang lain karena masalah penyakitnya ataupun pasca mastektomi. Pada masalah spiritual terdapat pasien yang lebih mendekatkan diri dengan sang pencipta adapula yang menyalahkan dan kecewa dengan sang pencipta (Tsitsis \& Lavdaniti, 2014). Masalah kualitas hidup yang sering terjadi adalah pandangan secara subjektif mengenai masalah fisik, psikologis, sosial, dan spiritual.

Kualitas hidup pasien kanker dipengaruhi oleh pendidikan, usia, pekerjaan, pendapatan, status pernikahan, stadium kanker, dan dukungan keluarga (Lopez et al., 2011). Kualitas hidup pada pasien kanker payudara menurun dua kali lipat setelah operasi pengangkatan payudara terutama masalah psikologis. Kualitas hidup kanker payudara secara klinis menurun setelah terdiagnosa dan terus menurun secara periodik setiap lima tahun setelah terdiagnosa kanker payudara (DiSipio, Hayes, Newman, Aitken, \& Janda, 2010). Dukungan keluarga dan lingkungan meningkatkan kualitas hidup pasien kanker payudara terutama masalah psikologis dan sosial walaupun secara fisik mengalami penurunan (Yanez, Thompson, \& Stanton, 2011).

Kualitas hidup pasien kanker payudara dapat ditingkatkan dengan terapi modern. Jenis-jenis terapi modern diantaranya adalah terapi radiasi, kemoterapi, pembedahan, dan kombinasi (Wolff et al., 2007). Dari berbagai jenis terapi modern, di Indonesia kemoterapi menjadi terapi yang sering digunakan sehubungan dengan kondisi pasien yang late diagnosed. Meskipun kemoterapi banyak memberikan hasil positif, di sisi lain banyak menimbulkan efek samping seperti mual muntah, penurunan sel darah merah (RBC), penurunan sel darah puih (WBC/leukosit), penurunan jumlah trombosit, mukositis, rambut rontok, dan gangguan saraf tepi (National Cancer Institute, 2007). Kemoterapi diberikan secara bertahap, biasanya sebanyak enam sampai delapan siklus agar mendapat efek yang diharapkan dengan efek samping yang masih bisa diterima. Hasil pemeriksaan imunohistokimia memberikan beberapa pertimbangan penentuan regimen kemoterapi yang akan diberikan (Kementrian Kesehatan Republik Indonesia, 2015). Sebagian besar pasien kanker payudara setelah menjalani kemoterapi memiliki kualitas hidup sedang (Heydarnejad et al., 2009; Pradana, Nuryani, Siluh, Wayan, 2012).

Selain efek samping, terapi modern untuk penderita kanker payudara pada stadium 
Erna Irawan : Hubungan Penggunaan Terapi Modern dan Komplementer

lanjut sangat sulit dan hasilnya dinilai kurang memuaskan (Manuaba, 2008). Karenanya dalam memaksimalkan pengobatan dan mengurangi efek samping terapi modern, penderita kanker payudara banyak menggunakan terapi komplementer (Saquib et al., 2012).

Penelitian mengenai terapi modern dan komplementer telah dilakukan di berbagai negara. Menurut Saini et al. (2011), nilai kualitas hidup pengguna terapi modern dan komplementer (herbal, diet khusus, dan praktek berbasis tubuh) lebih rendah dari pengguna terapi modern. Sedangkan menurut Kang et al. (2012) tidak ada perbedaan yang signifikan antara kualitas hidup pasien yang menggunakan terapi modern dan komplementer dengan pasien yang hanya menggunakan terapi modern saja dan menurut Gerber, Scholz, Reimer, Briese, dan Janni (2006) menunjukkan tidak adanya hubungan yang signifikan antara terapi modern dan komplementer dengan kualitas hidup pasien kanker payudara.

Hasil tersebut berbanding terbalik dengan penelitian Damodar, Smitha, Gopinath, Vijayakumar, dan Rao (2013) dan Donatelle dan Rebsxaecca (2004) yang menjukkan adanya hubungan positif yang signifikan antara terapi modern dan komplementer dengan kuaitas hidup pasien kanker payudara. Masyarakat cenderung menggunakan terapi komplementer karena banyak terapi yang menjanjikan kesembuhan $100 \%$ dan bisa mengobati berbagai jenis penyakit namun belum banyak penelitian yang membuktikannya (Dinas Kesehatan Kota Bandung, 2016).

Studi pendahuluan menunjukkan bahwa pengguna terapi modern sering mengeluh mual muntah terutama pasca kemoterapi. Pengguna terapi modern dan komplementer (pijat) mengatakan penggunaan pijat mengurangi lelah dan nyeri pasca terapi modern dilakukan. Pengguna terapi modern dan komplementer (herbal) mengatakan penggunaan herbal mengurangi mual muntah dan mempercepat penyembuhan pasca terapi modern dilakukan. Pengguna terapi modern dan komplementer (herbal dan pijat) mengatakan penggunaan herbal dan pijat untuk mengurangi efek samping terapi modern.

\section{Metode Penelitian}

Desain penelitian ini adalah jenis correlation cross sectional dimana melihat hubungan variabel independen yaitu kombinasi terapi modern dan komplementer (pijat, herbal serta, pijat dan herbal) dengan variabel dependen yaitu kualitas hidup pasien kanker payudara. Jenis terapi pijat yang terdapat dalam penelitian ini adalah terapi pijat tradisional dan pijat refleksi sedangkan jenis herbal yang terdapat dalam penelitian ini adalah sirsak, bawang cina, dan kunyit.

Populasidalampenelitianiniadalah seluruh penderita kanker payudara di Puskesmas Sekota Bandung dan Rumah Singgah Viona Lautan Kasih yang berjumlah 320 orang. Responden direkrut menggunakan accidental sampling selama tiga bulan berdasarkan kriteria inklusi responden adalah wanita yang berusia lebih dari 30 tahun. sehingga didapatkan jumlah sampel 178 orang.

Instrumen terdiri dari empat jenis kuesiner yaitu data demografi, terapi modern, terapi komplementer, dan kualitas hidup pasien kanker payudara. Pada data demografi dibuat berdasarkan penelitian Lopez et al., (2011) yang meliputi nomor urut responden, pendidikan, usia, pekerjaan, penghasilan, status pernikahan, stadium kanker, dan dukungan keluarga. Instrumen penelitian tentang terapi modern berdasarkan hasil penelitian Saini et al., (2011). Terdapat 1 pertanyaan yaitu jenis terapi modern yang digunakan. Instrumen untuk mengukur terapi komplementer dari hasil penelitian Noeres, Grabow, Sperlich, \& Belmann (2013), terdiri dari satu pertanyaan yaitu jenis terapi komplementer yang digunakan. Adapun kualitas hidup diukur menggunakan kuesioner EORTC (Europe Organization for Research and Treatment of Cancer) yang merupakan sistem terintegrasi untuk menilai kualitas hidup yang berhubungan dengan keadaan pada pasien-pasien kanker yang berpartisipasi pada uji klinik secara internasional. Kuesioner EOTC QLQ C-30 berisi 30 pertanyaan mengenai kualitas hidup khusus pasien kanker. Terjemahan dan validasi EORTC-QLQ-C30 ke dalam versi Indonesia untuk pasien kanker di Indonesia dilakukan oleh Perwitasari et al (2011).

Hasil uji validitas untuk semua item 
Erna Irawan : Hubungan Penggunaan Terapi Modern dan Komplementer

kuesioner menunjukkan semua data valid, karena semua item memiliki nilai koefisien korelasi $>0,30$. Hasil uji reliabilitas pada instrumen data demografi didapatkan nilai koefisien alpha sebesar 0,814, dukungan keluarga sebesar 0.899 , dan kualitas hidup 0,940. Artinya, semua instrumen tersebut dapat dikatakan reliabel dan memiliki hasil nilai reliabilitas tinggi karena nilai alpha cronbach lebih dari 0,70 .

Analisis data univariat disajikan untuk menggambarkan frekuensi dan persentase karekteristik responden, terapi modern, terapi modern dan komplementer, serta kualitas hidup. Analisis bivariat digunakan untuk menguji hipotesis adanya hubungan antara jenis terapi (modern dan komplementer dengan kualitas hidup pasien kanker payudara) menggunakan Spearman, dengan tingkat kemaknaan $(\alpha=0,01)$.

\section{Hasil Penelitian}

Data karekteristik responden terdiri dari usia, pendidikan, pekerjaan, penghasilan, status

Tabel 1 Distribusi Frekuensi Karekteristik Pasien Kanker Payudara $(\mathbf{N}=178)$

\begin{tabular}{|c|c|c|c|c|c|c|c|c|c|c|}
\hline \multirow[t]{2}{*}{$\begin{array}{c}\text { Karakteristik } \\
\text { Responden }\end{array}$} & \multicolumn{2}{|c|}{$\begin{array}{c}\text { Terapi Modern } \\
\mathbf{N}=\mathbf{6 0}\end{array}$} & \multicolumn{2}{|c|}{$\begin{array}{c}\text { Terapi Modern } \\
\text { dan Pijat } \\
\mathbf{N}=\mathbf{4 1}\end{array}$} & \multicolumn{2}{|c|}{$\begin{array}{c}\text { Terapi Modern } \\
\text { dan Herbal } \\
\mathbf{N}=\mathbf{5 1}\end{array}$} & \multicolumn{2}{|c|}{$\begin{array}{c}\text { Terapi Modern, } \\
\text { Pijat, dan Herbal } \\
\mathbf{N}=\mathbf{2 6}\end{array}$} & \multicolumn{2}{|c|}{$\begin{array}{c}\text { Total } \\
N=178\end{array}$} \\
\hline & $\mathbf{F}$ & $\%$ & $\mathbf{F}$ & $\%$ & $\mathbf{F}$ & $\%$ & $\mathbf{F}$ & $\%$ & $\mathbf{F}$ & $\%$ \\
\hline \multicolumn{11}{|l|}{ Usia } \\
\hline Dewasa Akhir (36-45) & 4 & 2,2 & 10 & 5,6 & 9 & 5,1 & 1 & 0,6 & 24 & 13,5 \\
\hline Lansia Awal (46-55) & 56 & 31,5 & 31 & 17,4 & 41 & 23,0 & 16 & 9,0 & 144 & 80,9 \\
\hline Lansia Akhir (56-65) & 0 & 0,0 & 0 & 0,0 & 1 & 0,6 & 9 & 5,1 & 10 & 5,6 \\
\hline \multicolumn{11}{|l|}{ Pendidikan } \\
\hline Tidak Sekolah & 1 & 0,6 & 2 & 1,1 & 1 & 0,6 & 3 & 1,7 & 7 & 3,9 \\
\hline SD & 25 & 14,0 & 11 & 6,2 & 16 & 9,0 & 12 & 6,7 & 64 & 36,0 \\
\hline SMP & 24 & 13,5 & 10 & 5,6 & 17 & 9,6 & 6 & 3,4 & 57 & 32,0 \\
\hline SMA & 7 & 3,9 & 14 & 7,9 & 15 & 8,4 & 4 & 2,2 & 40 & 22,5 \\
\hline Perguruan Tinggi & 3 & 1,7 & 4 & 2,2 & 2 & 1,1 & 1 & 0,6 & 10 & 5,6 \\
\hline \multicolumn{11}{|l|}{ Pekerjaan } \\
\hline Tidak Bekerja & 48 & 27,0 & 29 & 16,3 & 40 & 22,5 & 23 & 12,9 & 140 & 78,7 \\
\hline Bekerja & 12 & 6,7 & 12 & 6,7 & 11 & 6,2 & 3 & 1,7 & 38 & 21,3 \\
\hline Penghasilan & & 0,0 & & 0,0 & & 0,0 & & 0,0 & & 0,0 \\
\hline$<$ UMR (2.148.000) & 23 & 12,9 & 20 & 11,2 & 12 & 6,7 & 7 & 3,9 & 62 & 34,8 \\
\hline UMR (2.148.000) & 37 & 20,8 & 21 & 11,8 & 39 & 21,9 & 19 & 10,7 & 116 & 65,2 \\
\hline \multicolumn{11}{|l|}{ Status Pernikahan } \\
\hline Menikah & 46 & 25,8 & 25 & 14,0 & 41 & 23,0 & 17 & 9,6 & 128 & 71,9 \\
\hline Tidak Menikah & 3 & 1,7 & 3 & 1,7 & 2 & 1,1 & 3 & 1,7 & 12 & 6,7 \\
\hline Janda & 11 & 6,2 & 13 & 7,3 & 8 & 4,5 & 6 & 3,4 & 38 & 21,3 \\
\hline \multicolumn{11}{|l|}{ Stadium } \\
\hline III & 39 & 21,9 & 32 & 18,0 & 37 & 20,8 & 17 & 9,6 & 124 & 69,7 \\
\hline IV & 21 & 11,8 & 9 & 5,1 & 14 & 7,9 & 9 & 5,1 & 54 & 30,3 \\
\hline \multicolumn{11}{|l|}{ Dukungan Keluarga } \\
\hline Sangat Mendukung & 31 & 17,4 & 23 & 12,9 & 36 & 20,2 & 9 & 5,1 & 99 & 55,6 \\
\hline Cukup Mendukung & 21 & 11,8 & 16 & 9,0 & 14 & 7,9 & 12 & 6,7 & 63 & 35,4 \\
\hline Kurang Mendukung & 8 & 4,5 & 2 & 1,1 & 1 & 0,6 & 5 & 2,8 & 16 & 9,0 \\
\hline
\end{tabular}


Erna Irawan : Hubungan Penggunaan Terapi Modern dan Komplementer

Tabel 2 Distribusi Frekuensi Terapi Modern dan Komplementer yang Digunakan Penderita Kanker Payudara $(\mathbf{N}=\mathbf{1 7 8})$

\begin{tabular}{lcc}
\hline \multicolumn{1}{c}{ Terapi } & F & \% \\
\hline $\begin{array}{l}\text { Terapi Modern dan Komplementer } \\
\text { (Pijat, Herbal, serta Pijat dan } \\
\text { Herbal) }\end{array}$ & & \\
\hline Terapi Modern & 60 & 33,71 \\
Terapi Modern dan Pijat & 41 & 23,03 \\
Terapi Modern dan Herbal & 51 & 28,65 \\
Terapi Modern, Pijat, dan Herbal & 26 & 14,61 \\
Jenis Terapi Modern & & \\
Kemoterapi & 21 & 35,00 \\
Kemoterapi dan bedah & 8 & 13,30 \\
Kemoterapi dan radioterapi & 25 & 41,70 \\
Kombinasi (Kemoterapi, Radioterapi, & 6 & 10,00 \\
dan Bedah) & & \\
Jenis Terapi Modern dan Pijat & 7 & 17,10 \\
Kemoterapi dan pijat & 20 & 48,80 \\
Kemoterapi, bedah dan pijat & 13 & 31,70 \\
Kemoterapi, radioterapi dan pija & 1 & 2,44 \\
Kombinasi dan pijat & & \\
Jenis Terapi Modern dan Herbal & 16 & 29,00 \\
Kemoterapi dan herbal & 32 & 60,40 \\
Kemoterapi, bedah, dan herbal & 3 & 0,60 \\
Kemoterapi, radioterapi, dan herbal & & \\
Jenis Terapi Modern, Pijat, dan & 7 & 26,90 \\
Herbal & & \\
Kemoterapi, pijat, dan herbal & & 46,20 \\
Kemoterapi, bedah, pijat, dan herbal & & \\
Kemoterapi, radioterapi, pijat, dan \\
herbal
\end{tabular}

pernikahan, stadium, dan dukungan keluarga responden penelitian.

Tabel 1 dapat menggambarkan bahwa responden terdiri dari karekteristik lansia awal $(80,9 \%)$, tidak bekerja $(78,7 \%)$, berpenghasilan lebih dari UMR $(65,2 \%)$, menikah (71,9\%), kanker stadium III $(69,7 \%)$, dan memiliki dukungan keluarga yang sangat mendukung $(55,6 \%)$. Secara pendidikan, kelompok terbesar berpendidikan SD $(36,0 \%)$. Terkait Jenis terapi modern dan komplementer yang digunakan oleh responden dapat terlihat pada tabel 2 .

Tabel 2 menunjukkan, padapenggunaterapi modern dan komplementer (pijat, herbal, serta pijat dan herbal) sebagian pengguna terapi modern $(33,71 \%)$. Pada pengguna terapi modern sebagian menggunakan kemoterapi dan radioterapi (41,70\%). Sedangkan pada pengguna terapi modern dan pijat, sebagian menggunakan kemoterapi, bedah, dan pijat $(48,80 \%)$. Kemudian pada pengguna terapi modern dan herbal, sebagian besar menggunakan kemoterapi, bedah, dan herbal $(60,40 \%)$. Sedangkan pada pengguna terapi modern, pijat, dan herbal, sebagian menggunakan kemoterapi, radioterapi, pijat, dan herbal $(46,20 \%)$.

Hubungan antara karekteristik responden dengan kualitas hidup dan hubungan terapi modern dan kualitas hidup dianalisis menggunakan Spearman. Hubungan 
Erna Irawan : Hubungan Penggunaan Terapi Modern dan Komplementer

Tabel 3 Hubungan Karekteristik Responden terhadap Kualitas Hidup Pasien Kanker Payudara

\begin{tabular}{|c|c|c|c|c|}
\hline \multirow[t]{2}{*}{ Karakteristik Responden } & \multicolumn{3}{|c|}{$\begin{array}{c}\text { Terapi Modern } \\
\mathbf{N}=\mathbf{6 0}\end{array}$} & \multirow[t]{2}{*}{ p-Value } \\
\hline & Kurang & Sedang & Baik & \\
\hline \multicolumn{5}{|l|}{ Usia } \\
\hline Dewasa Akhir (36-45) & 0 & 18 & 6 & \\
\hline Lansia Awal (46-55) & 0 & 122 & 22 & 0,290 \\
\hline Lansia Akhir (56-65) & 0 & 4 & 6 & \\
\hline \multicolumn{5}{|l|}{ Pendidikan } \\
\hline Tidak Sekolah & 0 & 4 & 2 & \\
\hline SD & 0 & 55 & 10 & 0,364 \\
\hline SMP & 0 & 48 & 9 & \\
\hline SMA & 0 & 29 & 11 & \\
\hline Perguruan Tinggi & 0 & 8 & 2 & \\
\hline \multicolumn{5}{|l|}{ Pekerjaan } \\
\hline Tidak Bekerja & 0 & 114 & 26 & 0,732 \\
\hline Bekerja & 0 & 30 & 8 & \\
\hline \multicolumn{5}{|l|}{ Penghasilan } \\
\hline <UMR (2.148.000) & 0 & 52 & 10 & 0,464 \\
\hline UMR (2.148.000) & 0 & 92 & 24 & \\
\hline \multicolumn{5}{|l|}{ Status Pernikahan } \\
\hline Menikah & 0 & 99 & 29 & \\
\hline Tidak Menikah & 0 & 9 & 3 & 0,034 \\
\hline Janda & 0 & 36 & 2 & \\
\hline \multicolumn{5}{|l|}{ Stadium } \\
\hline III & 0 & 93 & 31 & 0,002 \\
\hline IV & 0 & 51 & 3 & \\
\hline \multicolumn{5}{|l|}{ Dukungan Keluarga } \\
\hline Sangat Mendukung & 0 & 80 & 19 & \\
\hline Cukup Mendukung & 0 & 49 & 14 & 0,001 \\
\hline Kurang Mendukung & 0 & 15 & 1 & \\
\hline
\end{tabular}

karekteristik responden dengan kualitas hidup dapat dilihat pada tabel 3.

Pada tabel 3, stadium memiliki hubungan positif yang signifikan dengan kualitas hidup dengan $p$-value $=0,002$ dan dukungan keluarga memiliki hubungan positif yang signifikan dengan kualitas hidup dengan $p$-value $=0,001$. Sedangkan hubungan antara terapi modern dan komplementer terhadap kualitas hidup dapat dilihat pada tabel 4.

Tabel 4, terdapat hubungan positif yang signifikan antara terapi modern dan komplementer terhadap kualitas hidup pasien kanker payudara $p$-value $=0,00$ dan $\rho$ (rho) $=+0,2$. Terdapat hubungan positif yang signifikan antara terapi modern terhadap kualitas hidup pasien kanker payudara $\mathrm{p}$-value $=0,00$ dan $\rho$ (rho) $=+0,5$. Terdapat hubungan positif yang signifikan antara terapi modern dan herbal terhadap kualitas hidup pasien kanker payudara $\mathrm{p}$-value $=0,00$ dan $\rho$ $(r h o)=+0,4$. Namun tidak terdapat hubungan negatif yang signifikan antara terapi modern dan pijat terhadap kualitas hidup pasien 
Erna Irawan : Hubungan Penggunaan Terapi Modern dan Komplementer

Tabel 4 Hubungan Terapi Modern dan Komplementer (Pijat, Herbal, Pijat dan Herbal) terhadap Kualitas Hidup Kanker Payudara

\begin{tabular}{|c|c|c|c|c|c|}
\hline \multirow{2}{*}{ Terapi } & \multicolumn{3}{|c|}{$\begin{array}{c}\text { Kualitas Hidup } \\
\%\end{array}$} & \multirow{2}{*}{ p-Value } & \multirow{2}{*}{$\rho(\mathrm{RHO})$} \\
\hline & Kurang & Sedang & Baik & & \\
\hline \multicolumn{6}{|l|}{ Terapi Modern dan Komplementer } \\
\hline Terapi modern & 0 & 52 & 8 & & \\
\hline Terapi modern dan pijat & 0 & 38 & 3 & $\mathbf{0 , 0 0}$ & $+0,2$ \\
\hline Terapi modern dan herbal & 0 & 39 & 12 & & \\
\hline Terapi modern, pijat, dan herbal & 0 & 18 & 8 & & \\
\hline \multicolumn{6}{|l|}{ Terapi Modern } \\
\hline Kemoterapi & 0 & 21 & 0 & & \\
\hline Kemoterapi dan bedah & 0 & 6 & 2 & 0,00 & $+0,5$ \\
\hline Kemoterapi dan radioterapi & 0 & 25 & 0 & & \\
\hline $\begin{array}{l}\text { Kombinasi (Kemoterapi, Radioterapi, } \\
\text { dan Bedah) }\end{array}$ & 0 & 0 & 6 & & \\
\hline \multicolumn{6}{|l|}{ Terapi Modern dan Pijat } \\
\hline Kemoterapi dan pijat & 0 & 7 & 0 & & \\
\hline Kemoterapi, bedah dan pijat & 0 & 19 & 1 & 0,57 & $-0,1$ \\
\hline Kemoterapi, radioterapi dan pija & 0 & 13 & 0 & & \\
\hline Kombinasi dan pijat & 0 & 1 & 0 & & \\
\hline \multicolumn{6}{|l|}{ Terapi Modern dan Herbal } \\
\hline Kemoterapi dan herbal & 0 & 16 & 0 & & \\
\hline Kemoterapi, bedah, dan herbal & 0 & 22 & 10 & 0,00 & $+0,4$ \\
\hline Kemoterapi, radioterapi, dan herbal & 0 & 1 & 2 & & \\
\hline \multicolumn{6}{|l|}{ Terapi Modern, Pijat, dan Herbal } \\
\hline Kemoterapi, pijat, dan herbal & 0 & 6 & 1 & & \\
\hline Kemoterapi, bedah, pijat, dan herbal & 0 & 6 & 0 & 0,41 & $+0,2$ \\
\hline $\begin{array}{l}\text { Kemoterapi, radioterapi, pijat, dan } \\
\text { herbal }\end{array}$ & 0 & 13 & 0 & & \\
\hline
\end{tabular}

kanker payudara $p$-value $=0,57$ dan $\rho$ (rho) $=-0,1$. Tidak terdapat hubungan positif yang signifikan antara terapi modern, pijat, dan herbal terhadap kualitas hidup pasien kanker payudara $p$-value $=0,41$ dan $\rho($ rho $)=+0,2$.

\section{Pembahasan}

Uji korelasi pada terapi modern dan komplementer terhadap kualitas hidup dengan Spearman mendapatkan hasil p-value $=0,00<\alpha=0,01$ dan $\rho$ (rho) $=+0,2$. Hasil tersebut menunjukkan bahwa terapi modern dan komplementer memiliki hubungan positif yang signifikan terhadap kualitas hidup pasien kanker payudara. Penggunaan terapi modern dan komplementer dapat meningkatkan kualitas hidup pasien kanker payudara. Hal ini sejalan dengan penelitian yang dilakukan Cheung et al. (2001); Sloman et al. (2003); Jacobsen et al. (2002); Stanley dan Konhauser (2011); dan Pederson dan David (2012). Namun, hasil tersebut berbading terbalik dengan penelitian Thompson et al. (2006). Perbedaan hasil penelitian dengan penelitian terdahulu dapat terjadi karena perbedaan jenis terapi komplementer dan perbedaan stadium, yang mana pada penelitian Thompson et al. (2006) sebagian besar responden termasuk stadium I dan II sedangkan penelitian ini stadium III. 
Erna Irawan : Hubungan Penggunaan Terapi Modern dan Komplementer

Uji korelasi pada terapi modern terhadap kualitas hidup dengan Spearman menunjukkan $p$-value $=0,00<\alpha=0,01$ dan $\rho($ rho $)=+0,4$. Hasil tersebut menunjukkan bahwa terapi modern memiliki hubungan positif yang signifikan terhadap kualitas hidup pasien kanker payudara. Penggunaan terapi modern dapat meningkatkan kualitas hidup pasien kanker payudara. Hal ini sejalan dengan penelitian yang dilakukan Byar, Bakken, dan Cetak (2006) serta Saini et al. (2011). Hasil ini sesuai dengan penelitian sebelumnya, karena terapi modern telah terbukti secara medis dan gejala-gejala yang ditimbulkan oleh penyakit kanker payudara dikurangi dengan terapi modern sehingga secara global kualitas hidup penderita kanker payudara meningkat.

Uji korelasi pada terapi modern dan pijat terhadap kualitas hidup dengan Spearman mendapatkan $p$-value $=0,57 ;<\alpha=0,01$; dan $\rho($ rho $)=-0,1$. Hasil tersebut menunjukkan bahwa terapi modern dan pijat tidak memiliki hubungan negatif yang signifikan terhadap kualitas hidup pasien kanker payudara. Penggunaan terapi modern dan pijat memiliki nilai negatif terhadap kualitas hidup, namun hubungannya tidak signifikan sehingga tidak membuktikan dapat menurunkan kualitas hidup pasien kanker payudara. Hal ini sejalan dengan penelitian yang dilakukan Alimi et al. (2000). Namun, hasil tersebut berbanding terbalik dengan penelitian Wilkie et al. (2000). Perbedaan hasil penelitian dengan peneltian terdahulu dapat terjadi karena perbedaan jenis terapi komplementer dan perbedaan stadium, yang mana pada penelitian Wilkie et al. (2000), sebagian besar responden termasuk stadium II sedangkan pada penelitian ini termasuk stadium III.

Uji korelasi pada terapi modern dan herbal terhadap kualitas hidup dengan Spearman mendapatkan $p$-value $=0,00 ;<\alpha=0,01$; dan $\rho($ rho $)=+0,4$. Hasil tersebut menunjukkan bahwa terapi modern dan herbal memiliki hubungan positif yang signifikan terhadap kualitas hidup pasien kanker payudara. Hal ini sejalan dengan penelitian yang dilakukan Sudarti dan Handojo (2002); Wang et al. (2016); Bao et al. (2012); dan Wu, Lai, \& Teal (2014). Berdasarkan hasil penelitian, penggunaan terapi modern dan herbal dapat meningkatkan kualitas hidup pasien kanker payudara. Namun, pada penelitian ini memiliki kelemahan yang mana tidak dikaji mengenai lama, intensitas, dan siapa pemberi herbal sehingga perlu pengkajian kembali mengenai hal tersebut oleh peneliti selanjutnya.

Uji korelasi pada terapi modern, pijat, dan herbal terhadap kualitas hidup dengan Spearman menunjukkan $p$-value $=0,41 ;>$ $\alpha=0,01$; dan $\rho($ rho $)=+0,2$. Hasil tersebut menunjukkan bahwa terapi modern, pijat, dan herbal tidak memiliki hubungan positif yang signifikan terhadap kualitas hidup pasien kanker payudara. Penggunaan terapi modern, pijat, dan herbal berhubungan positif dengan kualitas hidup, namun tidak signifikan sehingga tidak membuktikan dapat meningkatkan kualitas hidup pasien kanker payudara. Hal tersebut berbading terbalik dengan penelitian Kozikowski (2008). Perbedaan hasil penelitian dapat terjadi karena terdapat jenis terapi komplementer yang lain seperti akupuntur dan latihan otot progressive pada penelitian sebelumnya yang bisa saja membuat hubungan dengan kualitas hidup lebih signifikan.

\section{Simpulan}

Terdapat hubungan positif yang signifikan antara terapi modern dan komplementer terhadap kualitas hidup, terapi modern terhadap kualitas hidup, terapi modern dan herbal terhadap kualitas hidup pada pasien kanker payudara yang menjalani kemoterapi. Namun, tidak terdapat hubungan negatif yang signifikan antara terapi modern dan pijat terhadap kualitas hidup dan tidak terdapat hubungan positif yang signifikan antara terapi modern, pijat, dan herbal terhadap kualitas hidup pada pasien kanker payudara yang menggunakan kemoterapi.

\section{Daftar Pustaka}

Alimi D, Rubino C, Pichard-Leandri E, Fermand-Brule S, DubreuilLemaireML, Hill C (2003). Analgesic effect of auricular acupuncture forcancer pain: a randomized, blinded, controlled trial. J Clin Oncol, 21:4120-6. 
Erna Irawan : Hubungan Penggunaan Terapi Modern dan Komplementer

American Cancer Society.(2011). Insident and Prevalence Cancer, Atlanta: American Cancer Society, Inc.

Bao, P., Lu, W., Cui, Y., Zheng, Y., Gu, K., Chen, Z., ... Shu, X. O. (2012). Ginseng and Ganoderma lucidum Use after Breast Cancer Diagnosis and Quality of Life: A Report from the Shanghai Breast Cancer Survival Study, 7(6). https://doi.org/10.1371/journal. pone.0039343.

Byar, Bakken, \& Cetak. (2006).Oncology nursing society 36 th annual congress podium and poster abstracts. Oncology Nursing Forum, 38(3), E118-E180. https://doi. org/10.1188/11.ONF.E118-E180.

Cheung., et al. (2001). Knowledge, quality of life, and use of complementary and alternative medicine and therapies in inflammatory bowel disease: A Comparison of Chinese and Caucasian patients. Digestive Diseases and Sciences, 49(10), 1672-1676. https://doi. org/10.1023/B:DDAS.0000043384.26092. f4.

Damodar, Smitha, Gopinath, Vijayakumar, danRao. (2013). The Role of Chelation in the Treatment of Other Metal Poisonings. Journal of Medical Toxicology, 9, 355-369. http://doi.org/10.1007/s13181-013-0343-6.

DiSipio, T., Hayes, S.C., Newman, B., Aitken, J., \& Janda, M. (2010). Does quality of life among breast cancer survivors one year after diagnosis differ depending on urban and non-urban residence? A comparative study. Health and Quality of Life Outcomes, 8(3). http://doi.org/10.1186/1477-7525-8-3.

Donatelle \& Rebsxaecca. (2004). Prognosis following the use of complementary and alternative medicine in women diagnosed with breast cancer. Complementary Therapies in Medicine20(5), 283-290.https://doi. org/10.1016/j.ctim.2012.04.002.

Fatmadona., U. (2015). oleh National Comprehensive Cancer Network (NCCN) Pijat Terapetik Sebagai Evidence Based Practice Pada Pasien Kanker Untuk Mengurangi Distress. Ners Jurnal
Keperawatan. 11(1), 79-86.

Gerber, B., Scholz, C., Reimer, T., Briese, V., \& Janni, W. (2006). Complementary and alternative therapeutic approaches in patients with early breast cancer. A systematic review, 199-209. http://doi.org/10.1007/s10549005-9005-y.

Heydarnejadet al. (2009). What matters most in end-of-life care: Perceptions of seriously ill patients and their family members. Canadian Medical Association Journal, 174(5), 627633.

Jacobsen et al. (2002). Early palliative care for patients with metastatic non-small-cell lung cancer. The New England Journal of Medicine, 363, 733-742. https://doi. org/10.1056/NEJMoa1000678.

Kang, E., Yang, E.J., Kim, S.M., Chung, I.Y., Han, S.A., Ku, D.H., ..., Kim, S.W. (2012). Complementary and alternative medicine use and assessment of quality of life in Korean breast cancer patients: A descriptive study. Supportive Care in Cancer, 20, 461-473. http://doi.org/10.1007/s00520-011-1094-z.

Kozikowski (2008) Complementary, Alternative Therapy for Breast cancer. Search.proquest.com.

Lopez-class, M., Perret-gentil, M., Kreling, B., Caicedo, L., Mandelblatt, J., \& Graves, K. D. (2011). Quality of Life Among Immigrant Latina Breast Cancer Survivors: Realities of Culture and Enhancing Cancer Care, 724-733. http://doi.org/10.1007/s13187-0110249-4.

Manuaba. (2008). Gawat-Darurat ObstetriGinekologi \& Obstetri-Ginekologi Sosial untuk Profesi Bidan. Jakarta: EGC.

National Cancer Institute. (2007). Wolff, A. C., Hammond, M. E. H., Schwartz, J. N., Hagerty, K. L., Allred, D. C., Cote, R. J., ... Hayes, D. F. (2007). American Society of Clinical Oncology / College of American Pathologists Guideline Recommendations for Human Epidermal Growth Factor Receptor 2 Testing in Breast Cancer, 131(January). 
Erna Irawan : Hubungan Penggunaan Terapi Modern dan Komplementer

Ostad SN and Parsa M. (2011) Breast cancer from molecular point of view: pathogenesis and biomakers, breast cancer - focusing tumor microenvironment, stem cells and metastasis, ISBN:978-953-307-766-6, In Tech.

Pederson \& David. (2012). Triple-negative breast cancer: the impact of guidelineadherent adjuvant treatment on survival-a retrospective multi-centre cohort study. Springer Science+Business Media, LLC.

Pradana, I.P.W., Siluh, N., Nuryani, A., \& Surasta, W. (2012). Hubungan kualitas hidup dengan kebutuhan perawatan paliatif pada pasien kanker di RSUP Sanglah Denpasar. Universitas Udayana, Denpasar.

Kementrian Kesehatan Republik Indonesia. (2013). Situasi Penyakit Kanker di Indonesia. Pusat Data dan Informasi Kementrian Kesehatan RI. www.depkes.go.id.

Saini, A., Berruti, A., Capogna, S., Negro, M., Sguazzotti, E., Picci, R. L., ...Ostacoli, L. (2011). Prevalence of complementary/ alternative medicines (CAMs) in a cancer population in northern Italy receiving antineoplastic treatments and relationship with quality of life and psychometric features. Quality of Life Research, 20, 683-690. http:// doi.org/10.1007/s11136-010-9795-1.

Saquib, J., Parker, B.A., Natarajan, L., Madlensky, L., Saquib, N., Patterson, R.E., ..., Pierce, J.P. (2012). Prognosis following the use of complementary and alternative medicine in women diagnosed with breast cancer. Complementary Therapies in Medicine, 20(5), 283-290. http://doi. org/10.1016/j.ctim.2012.04.002.

Ds'set al. (2003). Care for the cancer caregiver : A systematic review.

Stanley, H. Kornhauser (2011) Why Cancer Patients Turn To Complementary \& Alternative Medicine (CAM) Therapies For Help. www.proquest.com.
Sudarti \& Handojo. (2002) Surgical treatment of early stage breast cancer in elderly: an international comparison. Springerlink.com.

Thompson et al. (2006). Complementary and alternative therapeutic approaches in patients with early breast cancer : a systematic review, 199-209. https://doi.org/10.1007/s10549005-9005-y.

Tsitsis \& Lavdaniti. (2014).Quality of Life in Women with Breast Cancer. International Journal of Caring Sciences, 7(1), 38-42.

Wang., et al. (2016). Re-thinking Ethnography of the Relationship between Biomedicine and Complementary and Alternative Medicine in Croatia.

Wilkie DJ, Kampbell J, Cutshall S, Halabisky $\mathrm{H}$, Harmon H, Johnson LP, et al. Effects of massage on pain intensity, analgesics and quality of life in patients with Breast cancer: a pilot study of a randomized clinical trial conducted within hospice care delivery. Hosp J 2000; 15:31-53.

Wolff, A.C., Hammond, M.E.H., Schwartz, J.N., Hagerty, K.L., Allred, D.C., Cote, R.J., ... Hayes, D.F. (2007). American Society of Clinical Oncology/College of American Pathologists Guideline Recommendations for Human Epidermal Growth Factor Receptor 2 Testing in Breast Cancer, 131(January).

Wu, C., Lai, J., \& Tsai, Y. (2014). The Prescription Pattern of Chinese Herbal Products That Contain Dang-Qui and Risk of Endometrial Cancer among TamoxifenTreated Female Breast Cancer Survivors in Taiwan: A Population-Based Study, 1-18. $\quad$ https://doi.org/10.1371/journal. pone. 0113887 .

Yanez, B., Thompson, E. H., \& Stanton, A. L. (2011). Quality of life among Latina breast cancer patients : a systematic review of the literature, 191-207. http://doi.org/10.1007/ s11764-011-0171-0. 